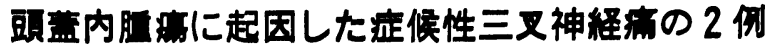

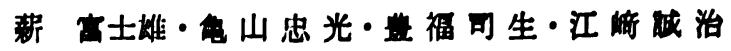 \\ 村濑宏・稗田照雄・朱得面道
}

\section{Two cases of false trigeminal neuralgia dut to with intracranial tumor}

\author{
Fujio Takıa - Tadamitsu Kameyama - Shisei Toyoruku \\ Seiji Esaki - Hiroshi Murase - Teruo Hieda \\ Chokudo Sujaku
}

\begin{abstract}
Two Cases of False Trigeminal Neuralgia due to Intracranial Tumor.
Case No. 1 was a 29-year-old male who visited our department with a main complaint of masticatory pain on the right temporomandibular joint region. CT scanning in the department of cerebrosurgery revealed a high density mass in the right cerebropontine angle region. Under the suspicion audiatory neurinoma, resection was done, which was then confirmed histopathologically.

Case No. 2 was a 56- year-old male who visited our department with a sricking pain on the right buccal region. CT scanning revealed a high density lesion in the parasellar. Under the suspicion of cerebral tumor, biopsy from the mass and trigeminal tractotomy were done and the histopathological diagnosis was metastatic adenoid cystic carcinoma. Although a detailed examination was performed, the primary lesion of this carcinoma could not be found.
\end{abstract}

Key words: intracranial tumor, trigeminal neuralgia, computerized tomography

緒

흠

口腔および顔面の疼痛は種々の病変によって引き起こ される1 そ) そのなかでも，症候性三叉神経痡は，われ われ歯科医にとって重要な疾患の1つである.

その原因疾患としては，種々あげられ歯科病変もその 1 つではあるか，他科領域の病変が本疾患の原因として

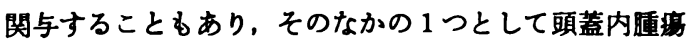
の報告がられる( 0).

最近われわれは，三叉神経痛を筑わせた頭蓋内腫婸を 2 例経験したので報告する.

久留米大学医学部口腔外科学講座

（主任：朱雀直道教授）

Department of Oral Surgery, Kurume University School of Medicine(Chief: Prof. Chokudo Sujaku)

受付日：昭和61年11月18日
症

\section{症例 1}

急者：29藏 男性。

初昭和58年10月回。

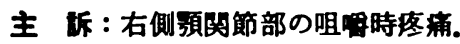

家族厢・展往愿：特記すべき事項なし。

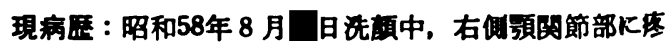
痛を自觉する。この庝痛は食索時，齿唐き時にも起こり 1 分間程持続した。 8 月回，某枓科受診，77の根管 治療を受けたが疼痛に变化なく某齿科へ枟医したとこ ろ，右側領関節部が原因で齿と関連がないといわれ放置 する. しかし疼痛発作が制回となり增大してきたため， 9 月下旬に其外科受診し当科を稆介される.

現 症：全身所見は異常なく顔面左右対称で右側領関 節部の腫脹はなく同部皮店に接蜰痛を認めた。開口障害 はなく $25 \mathrm{~mm}$ 開口時に右側䫑関節部にクリック音を認 


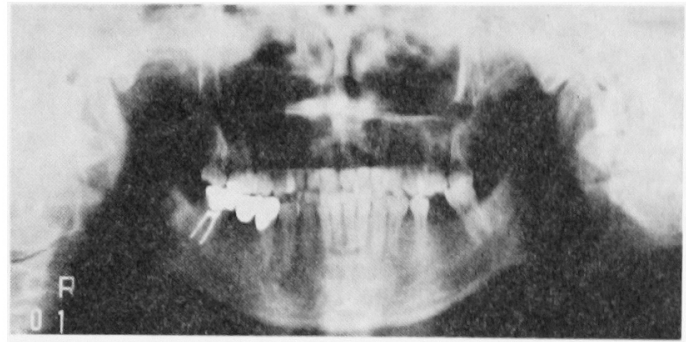

写南 1 症例 1 のオルソパントモ像

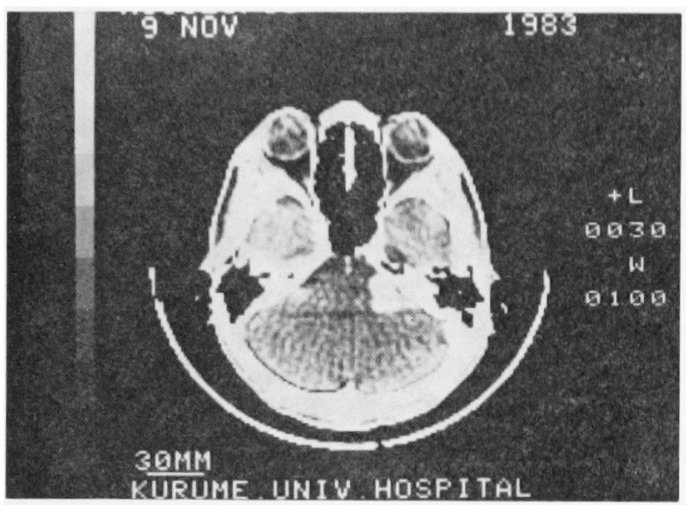

写真 2 症例 10 CT 像

めた。また同時に同部の疼痛と右側への箱の偏位を認め

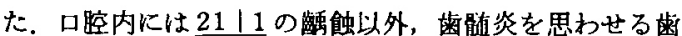
牙所見はなく，その他粘瞙にも異常はなかった。

臨床検査所見：血液検査，尿検査に異常は認められな かった。

X線所見：オルソハントモグラフィーおよび買関節部 オルビトラムス，側方開閉口時に抌いて特記すべき著変 は認められなかった（写直 1 ).

臨床診断：右額関節症の疑い。

処置および経過：上記にて消炎剂の投与と理学㙩法を 開始したところ疼痛増大のため表面皮膚に局麻を行った ところ疼痛の消失をみたため，三叉神释痛も否定でず 脳外科へ紹介する。脸外科にて神経侩查で右侧の聴力障 害, CT 検查にて右小脳橋角部に Contrast enhance さ れる high density mass がみられな拉小脳㧍よび楆 が内方一軽度王迫されている所見（写直 2)より聴神経 䩗腫の疑いの下，脳外科にて摘出手術を受ける。術後た たらに疼痛は消失し何ら障害を残すことなく治㦄した。

摘出物の病理組織学的診断は聴神経鞘腫であった（写 直 3 ).

\section{症例 2}

患 者: 56藏 男性.

初 診: 昭和58年 6 月日.

主 訴：右側煩部のピリピリ感.

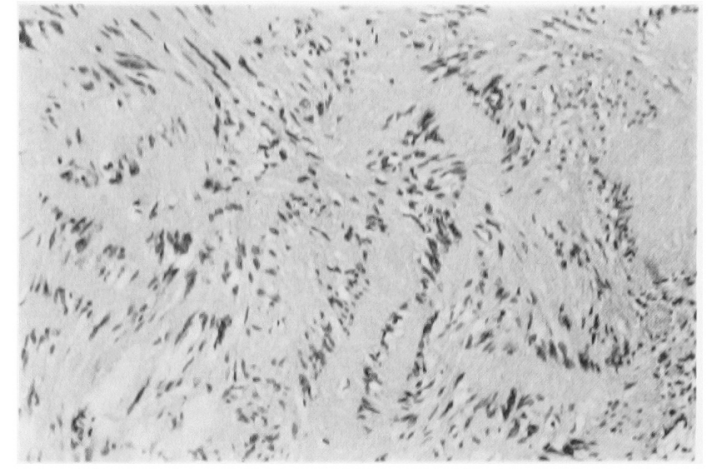

写真 3 症例 1 の病的紅維

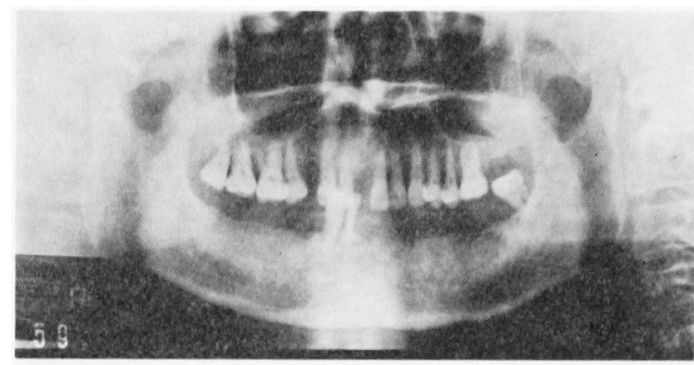

写真 4 症例 2 のオルンパントェ像

家族歷・既往歴：特記すべき事項なし.

現病歴：昭和58年3 月頁上り右側眼㸗下゙部，右侧上屡 部，右侧舞琶部および右侧煩部にかけて急にピリピリと した違和感を覚える，ただらに某籶科受診し，1週間程 投楽を受けたが変化がないため放固する。

しかし，1日に10回程電気が走る感じが科くため，5 月上旬某歯科に転医し，当科を紹介され受診する。

現 症：全身所見は異常なく顔面左右対称で左右上唇 部に拉いて，麻瘴感，接触痛は認められない。また右側 眼窩下部の王痛もない。開口障害はなく口腔内には $\frac{7+6}{32 \mid}$ が動摇度 2 度で全体に軽度の脉周病を認めるのみ で海髄炎を思わせる歯牙所見，根尖性崡周組織炎の急性 症状もなかった。

盬床検查所見：血液愉查，尿榆查に異常は認められな かった。

X線所見：オルソパントモグラフィー，顔面正面にお。 いて特記すべき著変は認められなかった（写真 4).

臨床診断：三叉神経痛の柔い。

処置および経過：初診日よりネオビタカインによる右 側眼窩下孔へのブロックを行い７回目にして疼痛発作が 完全に消失したため 6 月日にブロックを終了した。 と ころが8月にまた同様の疼痛発作が起きてきたため当大 麻酔科を受診し，同しく三叉神経痛の診断のもと，星状 神経節ブロックを 5〜6回受けた。しかし疼痛消失しな 


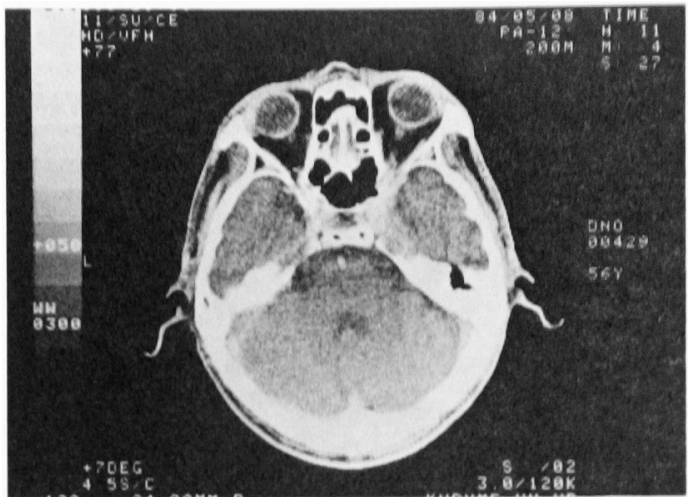

军正 5 拉例 2 の CT 像 (horizontal section)

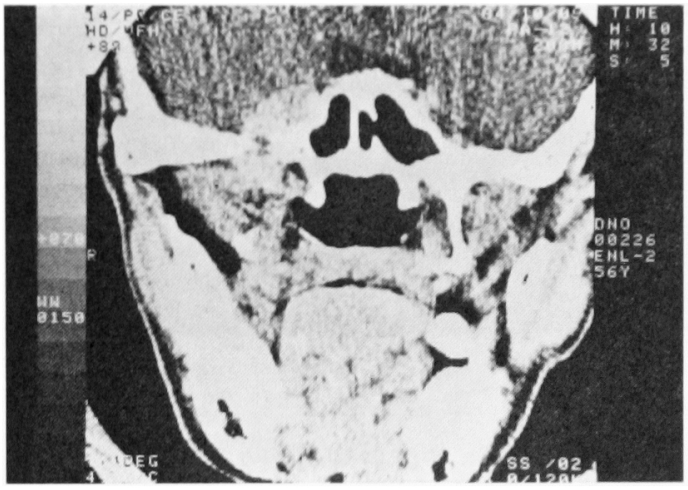

写查 6 症例 2 の CT 像 (coronal section)

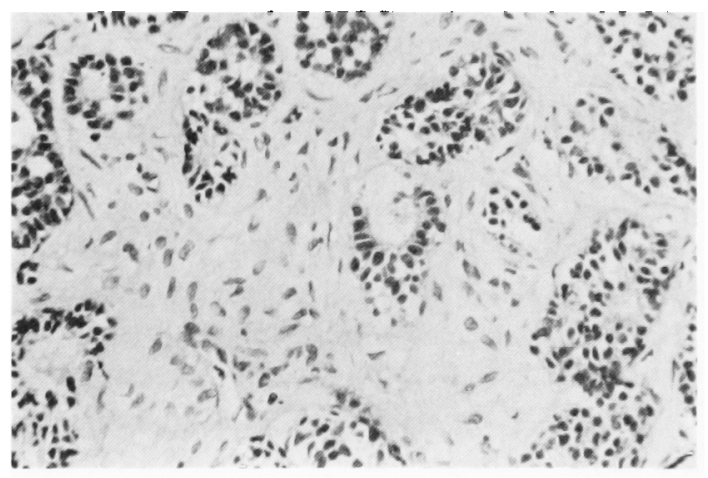

写奥 7 症例 2 の病理組織像

いため59年 2 月14日当大脳外科を受診し，CT 検查にて 脳腫湯が疑われる。すなわち horizontal section $の$ contrast enhancement CT で右の parasellar $K$ high density mass がみられ，錐体骨が一部破壊されている（写 真 5 ).

また, coronal sectionです同様の所見がみられ頭蓋底 骨が破壊され頭蓋外にも進展している像が得られた（写
立6).

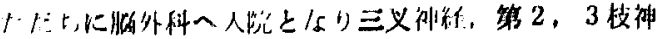

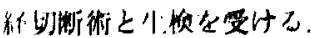

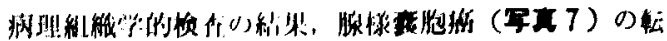

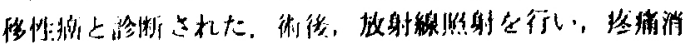

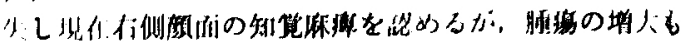

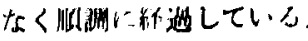

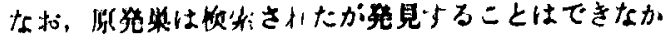
$21:$

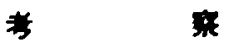

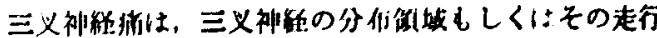

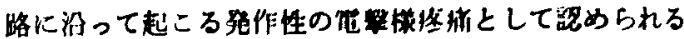

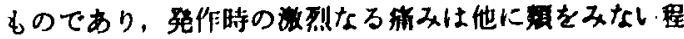
であるといわねている。

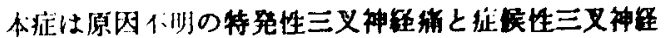
桷に分けられている，前者は，その原因として Neu rovascular compression theory ${ }^{10,11)}$ が考えられている.

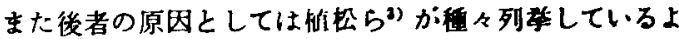

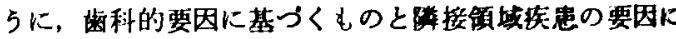
よるるのとに大きく分けられ，海科的要因が多く存在す るため，その爁別にあたり，われわれのところを訪れる 淀例む多い，しかし他の镇城の原因数多く，その整别 に当たっては，䇟接部位の原因についても䓡知している

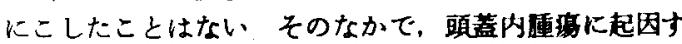
る症候性三叉神释痛恃重要なるのの1つである，原因の 探求をおこたり，対拉漅法のみに娢始することは傎しむ べきことで，今回の症例 2 では大いに反省すべきものと 考えている。

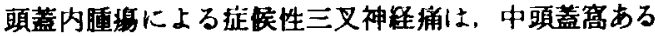

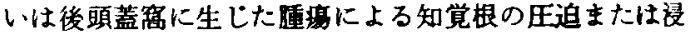
潤によって起こるとされてい・ろ5,12,13) 事実 Dandy ${ }^{14)}$ は 215例の三叉神程痛患者の開頭手術を行い, $5.6 \%$ 腫癁 が原因であったとしているる。ま，Revilla(s) b473例中 24 例 (5.1\%) に後頭蓋窝の尰楊をみている。ささらに Gardner ${ }^{16)}$ は三叉神軽痛の中で，㣫鸭に起因するるのと

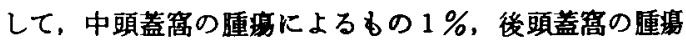
によるるのが $5 \%$ 程度存在するものと推定している.

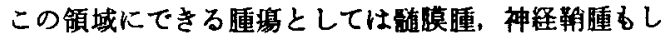
くは類上皮腫等がある $5,8,14,17$-10)。

事夷, Dandy ${ }^{14)}$ の開頭結果でる聴神程䩗腫と頛上皮睡 であったとされている. 本邦での植松ら”の報告る煩上 皮腫 4 例, 蹃膜腫 2 例, 聴神释腫湯が 1 例となってい る.

われわれの症例では，症例 1 が㯖神释䩗隀で従来の報 告通りであったか，症例 2 では転移性隀湰であった。

転移性脳腫湯の頻度は高く、脳腫煌の中で30\%を占め るとされている20,21)，1952年 Stortebecker ${ }^{22)}$ は150例に 
上る転移性脳腫瘦の神経学的筧点からの数告を行ってお

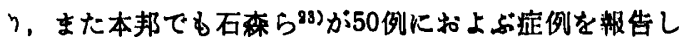
ている

それによると，脳転移の局在は，主に前頭莱にもっと も多く，頭項葉，側頭葉がこれにつつくとしている.

この前頭葉，侧頭葉は䫏蓋底面では，前述の中あるい

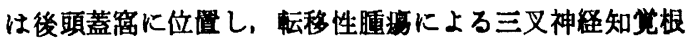
への浸潤は十分考えられる。

しかし，本症例のよらな腺様荡胞の忶移例について

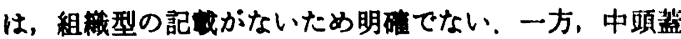
窝、啳頭蓋窝における原発珄后疗による神程症状は，神 経麻疩、頭痛、耳鳴り，難聴，めまい等があり，多くの 場合，これら2〜3の症状を随伴して起こるとされてい る.すなわち、三叉神释の害による顔面や口腔の知筧 鈍麻，聴神経障害による聴觉低下，耳鳴り，めまい，さ らに顔面神経障害による顫面麻疩や味觉脱出を伴5とさ れている，しかる疼痛の性質としては，今回の症例 1 の よらに発作性疼痛は少なく，脳王六進による普通持続的 な片頭痛様疼痛が主であるといわれている。

また，転移性脳腫瘍による神経症状は，Stortebecker ${ }^{22)}$ は脳圧六進を半数に，精神症状を $36 \%$ ，片麻瘏を $34 \%$ ， Jackson 座等を $28 \%$ に認めたとし，石來は 50 例中 28 例 に片麻疸を，ちっ血乳頭を24例，精神症状は13例にみら れたとしている．石森は，この神経症状の出現は急速に 起こり，これが一般の脳腫瘄と異なる点で，本疾患の 1 つの特缼としている．すなわち高度の脳圧六進を示すと し，三叉神経痛様症状をしめすのはまれである。

われわれが経鍳した症例 2 では，脳圧え進症状は少な く，腫場の唚潤による神経症状が強く出たことを考え合

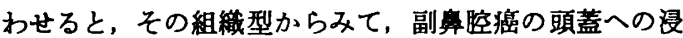
潤と考えると興味深い。

しかし今回経験した症例のように，これら神経学的異 常所見を欠如する報告例すみられる ${ }^{7,17)}$. そこで今回の 2 症例で真性三叉神経痛と異なる点を考えてみると，症 例 1 では疼痛が影関節部皮凮にみられたことと，当科で は見落としていたか，右側の聴力低下がみられたこと で, 症例 2 では, 疼痛の Trigger point が全くなかった ことである

しかし，数か月後の䐆外科受診時にはすでに，2， 3，4，5，6，7の神経の麻㾝が認められている。 し かしながら随伴症状を伴わない脳尰瘍による症候性三叉 神経痛の診断は容易ではない，そのためには CT 検查が きわめて有用な検査法であると考えられる。

以上のことより，三叉神経痛様疼痛を主訴としてきた 場合は，まず脳などに疼痛の原因となる器質的変化がな いかをみるために，神経症状のチェックを行うと同時に 脳外科での精査を行うべきと考えている.

そのらえ，三叉神経の根治的㞠法としては，後頭蓋神 経減窩術しかなく，その適応の判別もかねて，また診断
の硡运のため当科では，悩外科紹介を必ず行うことにし ている.

結 㮌

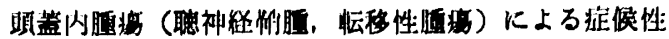
三叉神経痛の 2 例を经制したので報告した。

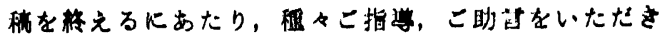

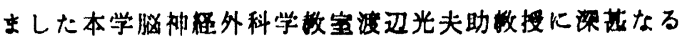
谢意を表します。

本淪文の要旨は，第30回日本口腔外科学会総会にて発 表した。

\section{引用 文 献}

1) Friedman, A.P. and Finley, K.H.: Classification of headache. Arch Neurol 6: 173-176 1962.

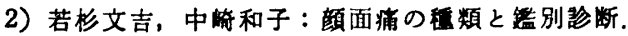
㳡科ジーーナル 18: 811-818 1983.

3）植松宏：症候性三叉神経痛。四科 ジャ一ナル 18: 827-835 1983 .

4) Weisenburg, T.H.: Cerebello-poutile tumor diagnosed for six years as Tic Douloureux: Sym ptomes of irritation of ninth and teach cranial nerve. JAMA 54: 1600-1604 1910.

5) McCurdy, J.A., Pitkethly, D.T., et al.: Central nerves system epidermoids presenting as trigeminal neuralgia. Surg Nenrol 2: 147-150 1974.

6）種子田護，長尾勇，他：三叉神経症状を呈した adenoid cytic carcinoma の 2 症例. 脳神释外科 10: 1005-1010 1976.

7）上田 孝, 乶屋朝和, 他: 三叉神経痛を呈した epidermoid cyst の 1 症例. 神経外科 23: 3753801983.

8) Hori, I. and Numata H.: Trigeminal pain caused by a parapontine epidermoid cyst. Surg Neurol 19: 517-519 1983.

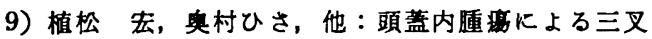
神経痛について。目麻誌 12: 646-656 1984.

10）福島孝徳: 三叉神経痛の外科的治瘄. 神経進歩 26: 982-991 1982 .

11）植松宏, 奧村ひさ, 他 : 特発性三叉神経痡に対 する三叉神経減王手術について。 日㐘麻誌 12: 540-549 1984.

12) Hamby, W.B.: Trigeminal neuralgia due to radicular lesions. Arch Surg 46: 555-563 1943.

13）太田富婎, 西村周郎：脳腫㾕の臨床症状. 第 3 版, 金芳堂, 京都 1978, 350頁.

14) Dandy, W.E.: Concerning the cause of trigeminal neuralgia. Amer J Surg 24: 447-455 1934.

15) Revilla, A.G.: Tic Douloureux and its relation- 
ship to tumors of posterior fossa: Analysis of cases. J Neurosurg 4: 233-239 1947.

16) Gardner, W.J.: Concerning the mechanism of trigeminal neuralgia and hemifacial spasm, J. Neurosurg 19: 947-958 1962.

17) Nijensohn, D.E., Araujo, J.C., et al.: Menirgioma of meckel's cave. J Neurosurg 43: 1972021975.

18) Baumann, C.H.H. and Bucy, P.C.: Paratrigeminal epidermoid tumors. J Neurosurg 13: 455-468 1956.

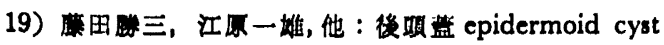

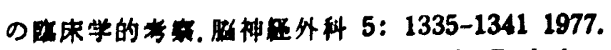

20) Anderson, W.A.D. and Risuane, J.M.: Pathology II , 7th Ed, Mosby Co, St Louis, 1977, p 21372138.

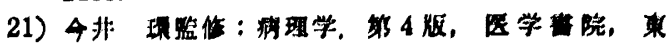
京, 1984，773面。

22) Stortebecker, T.P.: Metastatic tumors of the brain from a neurosurgical point of view. $J$ Neursurg 11: 84-111 1954.

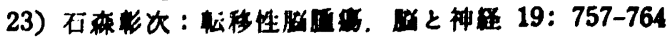
1967. 